\title{
KARAKTERISTIK INTUISI SISWA SMP DALAM MEMECAHKAN MASALAH MATEMATIKA DITINJAU DARI KEMAMPUAN MATEMATIKA
}

\author{
Anam Brammanto Satriyo Pamuji \\ Pendidikan Matematika, FMIPA, Universitas Negeri Surabaya, Email: anampamuji@mhs.unesa.ac.id \\ PradnyoWijayanti \\ Pendidikan Matematika, FMIPA, Universitas Negeri Surabaya, Email: pradnyowijayanti@unesa.ac.id
}

\begin{abstract}
Abstrak
Penelitian ini ditujukan untuk mendeskripsikan karakteristik intuisi siswa SMP dalam memecahkan masalah matematika ditinjau dari kemampuan matematika. Penelitian ini berjenis deskriptif kualitatif. Adapun subjek penelitian ini adalah tiga siswa kelas VIII A yang berasal dari SMP Labschool Unesa Surabaya yang terdiri dari siswa dengan kemampuan matematika tinggi, sedang, dan rendah. Metode pengumpulkan data menggunakan tes kemampuan matematika, tes pemecahan masalah serta metode wawancara. Analisis data mengunakan indikator karakteristik intuisi pada setiap tahap pemecahan masalah. Kesimpulan yang bisa diambil dari penelitian ini yaitu: siswa dengan kemampuan matematika tinggi pada tahap memahami masalah menggunakan intuisi affirmatory dengan karakteristik extrapolativeness, intrinsic certainty dan perseverance, pada tahap membuat rencana menggunakan intuisi anticipatory dengan karakteristik ide global, serta pada tahap melaksanakan rencana dan tahap memeriksa kembali tidak menggunakan intuisi. Siswa dengan kemampuan matematika sedang pada tahap memahami masalah menggunakan intuisi affirmatory dangan karakteristik extrapolativeness, intrinsic certainty dan perseverance, pada tahap membuat rencana menggunakan intuisi anticipatory dengan karakteristik ide global, serta pada tahap melaksanakan rencana dan tahap memeriksa kembali tidak menggunakan intuisi. siswa dengan kemampuan matematika rendah pada tahap memahami masalah menggunakan intuisi affirmatory dangan karakteristik perseverance dan coerciveness, pada tahap membuat rencana menggunakan intuisi anticipatory dengan karakteristik ide global, serta pada tahap melaksanakan rencana dan tahap memeriksa kembali tidak menggunakan intuisi.
\end{abstract}

Kata Kunci: intuisi, pemecahan masalah, kemampuan matematika

\begin{abstract}
The purpose of this study is to describe the intuition characteristics of junior high school students in solving mathematical problems viewed from mathematical abilities. This research based on qualitative descriptive study. The subjects of this study were taken from Lab School UNESA Junior High School, which consisted of three students from class VIII A, namely one student with high, moderate, and low mathematical ability. The method that used to collect data consists of the mathematical ability test, problem solving test and so of the interview method. Data analysis uses the intuitive characteristic indicators at each stage of the problem solving. The conclusion of this study indicate that student with high mathematical ability at the stage of understanding the problem using affirmatory intuition with the characteristics of extrapolativeness, intrinsic certainty and perseverance, at the stage of making plans using anticipatory intuition with the characteristics of global ideas, and at the stage of carrying out plans and checking again not using intuition. Student with moderate mathematical ability at the stage of understanding the problem using affirmatory intuition with the characteristics of extrapolativeness, intrinsic certainty and perseverance, at the stage of making plans using anticipatory intuition with the characteristics of global ideas, and at the stage of carrying out plans and checking again not using intuition. Student with low mathematical ability at the stage of understanding the problem using affirmatory intuition with the characteristics of perseverance and coerciveness, at the stage of making plans using anticipatory intuition with the characteristics of global ideas, and at the stage of carrying out plans and checking again not using intuition.
\end{abstract}




\section{KARAKTERISTIK INTUISI SISWA SMP...}

Keywords: intuition, problem solving, mathematics ability

\section{PENDAHULUAN}

Matematika tidak dapat lepas dari kehidupan. Setiap manusia tentunya merasakan bahwa matematika bermanfaat serta membawa kemudahan dalam kehidupan. Tanpa matematika manusia akan mengalami banyak kesulitan. Saat ini pengetahuan dasar dan keterampilan menggunakan matematika merupakan kemampuan yang harus dimiliki semua orang, terutama pada pembelajaran. Pembelajaran matematika di sekolah, berkaitan erat dengan pemecahan masalah. Dengan melakukan pemecahan masalah, kemampuan berpikir serta keterampilan matematika juga akan ikut terasah.

Polya (2004) mengartikan pemecahan masalah sebagai satu usaha mencari jalan keluar dari suatu kesulitan guna mencapai suatu tujuan yang tidak begitu mudah dicapai. Menurut Rahmadani (2012: 12) masalah matematika adalah masalah yang berkaitan dengan matematika, di mana diperlukan cara untuk menyelesaikannya. Dalam pembelajaran matematika, masalah yang dihadapkan kepada siswa berupa soal yang membutuhkan suatu penyelesaian. Akan tetapi belum tentu soal matematika merupakan sebuah masalah. Menurut Hudojo (2005) suatu soal dapat digolongkan menjadi masalah jika menantang untuk diselesaikan tetapi dapat dipahami oleh siswa dan tidak dapat diselesaikan dengan prosedur rutin yang telah diketahui siswa. Polya (2004) mengajukan empat langkah pemecahan masalah yaitu memahami masalah, membuat rencana, melaksanakan rencana, dan melakukan pengecekan kembali. Dalam implementasi kurikulum 2013, selain diharuskan untuk memahami konsep dari suatu pengetahuan, siswa juga dituntut mampu menyelesaikan masalah kontekstual sesuai dengan konsep yang dipelajari. Karena itu, siswa harus diberikan pengetahuan mengenai pemecahan masalah sehingga siswa memiliki kemampuan membangun ide dan siswa dapat berlatih menerapkan konsep yang telah dipelajari.

Dalam pemecahan masalah, diperlukan proses mental berupa proses berpikir analitik dan logika. Namun jika hanya mengandalkan dua proses itu saja siswa belum tentu dapat memperoleh jawaban dari masalah, karena dalam memecahkan masalah terkadang diperlukan dugaan atau klaim suatu pernyataan tanpa harus dengan membuktikan (Usodo, 2012). Oleh karena itu, diperlukan proses mental selain dari proses analitik dan logika dalam melaksanakan kegiatan matematika, termasuk memecahkan masalah matematika. Aktivitas mental tersebut disebut intuitive cognition (kognisi intuitif), atau intuition (intuisi).

Kata intuisi sering digunakan dalam kehidupan seharihari. Ada yang mengartikan intuisi sebagai perasaan, feeling, dan banyak lagi pengertian intuisi dalam percakapan sehari-hari, intuisi dipahami secara beragam dan tidak ada kesepakatan umum terhadap pengertian intuisi tersebut (Minggi, 2010: 54). Definisi intuisi menurut Fischbein (1987) yaitu kognisi segera dalam memperoleh dan memahami sesuatu tanpa bergantung pada suatu proses penalaran dan tanpa pembenaran atau bukti-bukti. Sedangkan Minggi (2010:57) mendefinisikan intuisi sebagai kognisi atau proses mental dalam memahami sesuatu, atau mengkonstruksi pengetahuan. Proses ini bersifat langsung, segera, dan tidak membutuhkan pembenaran. Berdasarkan berbagai pendapat di atas, dapat disimpulkan definisi intuisi merupakan suatu proses kognisi yang bersifat segera dalam memahami suatu objek atau memecahkan suatu masalah yang muncul secara subjektif dengan pembenaran menurut dirinya sendiri, langsung diterapkan, memaksa, tanpa prosedur atau strategi yang berurutan.

Menurut Fischbein (2002), berdasarkan perannya (roles) intuisi dikategorikan menjadi intuisi afirmatori (affirmatory intuition), intuisi antisipatori (anticipatory intuition), dan intuisi konklusif (conclusive intuition). Adapun karakteristik intuisi dalam memecahkan masalah dibedakan menjadi tiga, yaitu karakteristik intuisi afirmatori yang terdiri dari (1) direct, self-evident, (2) intrinsic certainty, (3) perseverance, (4) coerciveness, (5) extrapolativeness, dan (6) globality; karakteristik intuisi antisipatori yang terdiri dari (1) ide global dan (2) bertentangan dengan dugaan pada umumnya; serta karakteristik intuisi konklusif yang terdiri dari menyimpulkan secara umum (Usodo, 2011).

Banyak faktor yang mempengaruhi individu untuk memecahkan masalah matematika. Salah satunya adalah kemampuan matematika siswa. Menurut Syaban (2010: 59), kemampuan matematika adalah pengetahuan dan keterampilan yang diperlukan untuk dapat melakukan manipulasi matematika meliputi pemahaman konsep dan pengetahuan prosedural

Intuisi memiliki banyak peran dalam dunia pendidikan. Dahlan (2011) menyatakan bahwa intuisi merupakan dasar kemampuan tingkat tinggi dalam matematika dan ilmu lainnya. Selanjutnya, Hasanah dan Sahbandar (2010) menyatakan bahwa intuisi dapat mendorong kreativitas siswa dalam memilih ide dan strategi dalam memecahkan masalah, berperan saat harus memilih dan mengambil keputusan kritis. Dari pendapat para ahli sebelumnya, terlihat bahwa intuisi memiliki hubungan dengan pemecahan masalah

Dari pemaparan sebelumnya, peneliti tertarik untuk melakukan penelitian mengenai "Karakteristik Intuisi Siswa SMP dalam Memecahkan Masalah Matematika Ditinjau dari Kemampuan Matematika”. Adapun tujuan 
dari penelitian ini adalah untuk mendeskripsikan karakteristik intuisi siswa SMP dengan kemampuan matematika tinggi, sedang, dan rendah dalam memecahkan masalah matematika. Hasil penelitian ini diharapkan dapat memberikan manfaat, antara lain untuk memberikan gambaran pada peneliti tentang karakteristik intuisi siswa SMP dalam memecahkan masalah matematika, sebagai masukan bagi guru dalam mengembangkan metode pembelajaran yang sesuai dengan karakteristik intuisi siswa, serta sebagai rujukan bagi peneliti lain yang tertarik melakukan penelitian sejenis.

Adapun indikator yang digunakan dalam penelitian ini adalah sebagai berikut.

Tabel 1. Indikator Karakteristik Intuisi dalam Langkah-langkah Pemecahan Masalah Polya

\begin{tabular}{|c|c|c|}
\hline $\begin{array}{c}\text { Langkah } \\
\text { pemecahan } \\
\text { masalah } \\
\end{array}$ & $\begin{array}{l}\text { Karakteristik } \\
\text { Intuisi }\end{array}$ & Indikator \\
\hline \multirow[t]{6}{*}{$\begin{array}{l}\text { Memahami } \\
\text { Masalah }\end{array}$} & $\begin{array}{l}\text { Dirrect, Self- } \\
\text { evidence }\end{array}$ & $\begin{array}{l}\text { Siswa mampu } \\
\text { menentukan data } \\
\text { yang diketahui dan } \\
\text { ditanyakan pada soal } \\
\text { secara langsung tanpa } \\
\text { bantuan gambar atau } \\
\text { informasi tambahan } \\
\text { lainnya. }\end{array}$ \\
\hline & Intrinsic certainty & $\begin{array}{l}\text { Siswa menyatakan } \\
\text { bahwa informasi } \\
\text { yang diperolehnya } \\
\text { dari soal sudah pasti } \\
\text { benar tanpa } \\
\text { memerlukan } \\
\text { pembuktian (seperti } \\
\text { membaca berulang } \\
\text { atau menggunakan } \\
\text { gambar) }\end{array}$ \\
\hline & Perseverance & $\begin{array}{l}\text { Siswa } \\
\text { mempertahankan } \\
\text { informasi yang } \\
\text { diperolehnya }\end{array}$ \\
\hline & Coerciveness & $\begin{array}{l}\text { Siswa memaksa } \\
\text { bahwa informasi } \\
\text { yang diperolehnya } \\
\text { selalu benar. }\end{array}$ \\
\hline & Extrapolativeness & $\begin{array}{l}\text { Siswa dapat } \\
\text { menentukan ukuran } \\
\text { persegi yang belum } \\
\text { diketahui hanya } \\
\text { berdasarkan } \\
\text { informasi yang tertera } \\
\text { dalam soal. }\end{array}$ \\
\hline & Globality & $\begin{array}{l}\text { Siswa } \\
\text { merepresentasikan } \\
\text { informasi yang } \\
\text { diketahui pada soal } \\
\text { secara umum (tidak }\end{array}$ \\
\hline
\end{tabular}

\begin{tabular}{|c|c|c|}
\hline $\begin{array}{c}\text { Langkah } \\
\text { pemecahan } \\
\text { masalah }\end{array}$ & $\begin{array}{c}\text { Karakteristik } \\
\text { Intuisi }\end{array}$ & Indikator \\
\hline & & $\begin{array}{l}\text { secara detil atau } \\
\text { menggunakan } \\
\text { gambar) }\end{array}$ \\
\hline $\begin{array}{l}\text { Membuat } \\
\text { Rencana } \\
\text { Pemecahan } \\
\text { Masalah }\end{array}$ & Ide global & $\begin{array}{l}\text { Siswa menemukan } \\
\text { ide pemecahan } \\
\text { masalah dengan } \\
\text { menyimpulkan secara } \\
\text { umum apa yang } \\
\text { tertulis pada soal }\end{array}$ \\
\hline $\begin{array}{l}\text { Melaksanak } \\
\text { an Rencana }\end{array}$ & $\begin{array}{l}\text { Bertentangan } \\
\text { dengan dugaan } \\
\text { pada umumnya }\end{array}$ & $\begin{array}{l}\text { Siswa } \\
\text { mengemukakan } \\
\text { kendala yang } \\
\text { menyebabkan } \\
\text { perubahan rencana } \\
\text { yang telah ditentukan }\end{array}$ \\
\hline $\begin{array}{l}\text { Memeriksa } \\
\text { Kembali }\end{array}$ & $\begin{array}{l}\text { Menarik } \\
\text { kesimpulan }\end{array}$ & $\begin{array}{l}\text { Siswa menyimpulkan } \\
\text { secara umum (tidak } \\
\text { mengulang langkah- } \\
\text { langkah perhitungan } \\
\text { yang telah dilakukan) } \\
\text { berdasarkan ide awal } \\
\text { dan ide alternatif } \\
\text { yang telah diperoleh. }\end{array}$ \\
\hline
\end{tabular}

Penelitian ini berjenis deskriptif kualitatif dan bertujuan untuk memperoleh deskripsi dari karakteristik intuisi siswa yang dituangkan dalam kalimat dengan berbagai metode ilmiah.

Instrumen yang digunakan dalam penelitian ini berupa lembar soal tes kemampuan matematika (TKM), lembar tes pemecahan masalah (TPM), dan pedoman wawancara. Adapun teknik pengumpulan data yang digunakan yaitu metode tes dan metode wawancara.

Data dalam penelitian ini diambil dari tiga orang siswa SMP Labschool Unesa Ketintang Surabaya. Peneliti memilih lokasi ini dikarenakan belum pernah diadakan penelitian yang sejenis, selain itu peneliti memilih lokasi ini dengan mempertimbangkan kemudahan dikarenakan lokasi yang mudah dijangkau. Pengambilan data dilakukan pada bulan Januari 2020, di kelas VIII A. Pemilihan subjek didasarkan pada pertimbangan bahwa siswa kelas VIII telah memiliki pengetahuan yang cukup dalam menyelesaikan soal TKM dan TPM.

Penelitian ini menggunakan teknik analisis data sebagai berikut.

1. Analisis tes kemampuan matematika

Hasil TKM dianalisis kebenarannya berdasarkan pedoman penskoran. Setelah memperoleh data skor siswa, peneliti kemudian mengelompokkan siswa menjadi kelompok kemampuan matematika tinggi, sedang, dan rendah. Pengelompokan kemampuan matematika siswa menggunakan acuan yang diadaptasi 
dari penelitian oleh Sukmawati (2015: 58). Dalam acuan tersebut, siswa dinyatakan memiliki kemampuan matematika tinggi jika memperoleh skor $80 \leq \mathrm{x} \leq$ 100, memiliki kemampuan matematika sedang jika memperoleh skor $60 \leq x<80$, dan memiliki kemampuan matematika rendah jika memperoleh skor $0 \leq \mathrm{x}<60$.

2. Analisis tes pemecahan masalah

Dari masing-masing kelompok kemudian dipilih satu siswa sebagai subjek penelitian sehingga didapatkan tiga siswa sebagai subjek penelitian. Ketiga siswa kemudian lembar soal TPM. Data yang diperoleh dari hasil TPM dianalisis sesuai dengan kebutuhan peneliti. Analisis menggunakan jenis intuisi Fischbein (2002) yaitu intuisi affirmatory, intuisi anticipatory dan intuisi conclusive yang muncul saat siswa menyelesaikan masalah.

3. Analisis hasil wawancara

Ketiga siswa yang telah terpilih kemudian akan diwawancarai. Wawancara dibagi menjadi dua sesi, sesi pertama setelah siswa diberikan TPM masalah matematika, dengan tujuan untuk mengungkap intuisi siswa pada tahap memahami masalah dan membuat rencana pemecahan masalah. Sesi kedua setelah siswa mengerjakan TPM, dengan tujuan untuk mengungkap intuisi siswa pada tahap melaksanakan rencana dan memeriksa kembali.

Data yang telah diperoleh kemudian ditranskripkan sesuai dengan hasil di lokasi penelitian. Data yang sudah ditranskripkan selanjutnya direduksi, dan diberikan keterangan yang memudahkan dalam menyampaikan informasi.

\section{HASIL DAN PEMBAHASAN}

Dari 21 siswa kelas VIIIA SMP Labschool Unesa Ketintang Surabaya diambil 3 siswa untuk menjadi subjek penelitian melalui tes kemampuan matematika untuk diberikan tes pemecahan masalah dan kemudian diberikan lembar wawancara untuk menggali jawaban lebih dalam. Data hasil pekerjaan siswa dalam menjawab tes pemecahan masalah dan hasil wawancara dengan masingmasing siswa digunakan untuk membuat deskripsi karakteristik intuisi siswa SMP dalam memecahkan masalah matematika. Adapun subjek penelitian ini terdiri dari masing-masing siswa berkemampuan matematika tinggi, sedang, dan rendah. Berikut hasil dari penelitian yang telah dilakukan.

1. Karakteristik intuisi siswa yang memiliki kemampuan matematika tinggi dalam memecahkan masalah matematika

Dalam tahap memahami masalah, siswa dengan kemampuan matematika tinggi menggunakan intuisi affirmatory, hasil ini sesuai dengan penelitian dari
Nazariah dkk (2017). Adapun karakteristik yang terlihat pada siswa adalah extrapolativeness yang terlihat dari kemampuan siswa menentukan panjang sisi persegi yang belum diketahui dengan tepat, intrinsic certainty yang terlihat dari keyakinan siswa terhadap kebenaran informasi yang diperolehnya, dan perseverance yang terlihat saat siswa mempertahankan informasi yang diperolehnya. Siswa tidak langsung memahami soal saat pertama kali membacanya yang berarti bahwa siswa tidak menunjukkan adanya karakteristik direct self-evidence. Argumen siswa yang mendasarkan keyakinannya terhadap kebenaran informasi yang diperolehnya pada perhitungan matematis menunjukkan bahwa siswa tidak memperlihatkan karakteristik coerciveness. Siswa tidak merepresentasikan informasi yang ditemukannya pada lembar jawaban sehingga siswa tidak menunjukkan karakteristik globality.

Dalam tahap membuat rencana pemecahan masalah, siswa dengan kemampuan matematika tinggi menggunakan intuisi anticipatory dengan karakteristik ide global. Siswa menemukan ide pemecahan masalah itu melalui informasi yang didapatkannya dari soal tanpa bantuan informasi lain dari luar. Siswa menggunakan rumus $\frac{1}{2} \times$ alas $\times$ tinggi yang secara tidak langsung menunjukkan bahwa siswa menyimpulkan ide penyelesaian secara umum setelah melihat bentuk daerah yang diarsir. Siswa juga menyatakan bahwa ide yang dia temukan itu sudah pasti benar.

Dalam tahap melaksanakan rencana, siswa dengan kemampuan matematika tinggi tidak menggunakan intuisi, hasil ini sesuai dengan penelitian oleh Murdika (2013). Siswa melaksanakan ide awal yang sudah direncanakan tanpa ada penambahan atau pengurangan ide. Ini dikarenakan siswa tidak menemui kendala sehingga tidak perlu menggunakan intuisi dan hanya menggunakan operasi aljabar.

Dalam tahap memeriksa kembali, siswa dengan kemampuan matematika tinggi tidak menggunakan intuisi. Setelah siswa menemukan hasil akhir, yang dilakukan selanjutnya adalah mengulang perhitungan yang telah dilakukan dan memeriksa apabila ada kesalahan dalam penulisan. Kegiatan itu digunakan untuk menentukan penyelesaian masalah. Dari hal tersebut terlihat bahwa siswa tidak menggunakan intuisi.

2. Karakteristik intuisi siswa yang memiliki kemampuan matematika sedang dalam memecahkan masalah matematika 
Dalam tahap memahami masalah, siswa dengan kemampuan matematika sedang menggunakan intuisi affirmatory, hasil ini sesuai dengan penelitian oleh Murdika (2013). Adapun karakteristik yang terlihat pada siswa adalah extrapolativeness yang terlihat dari kemampuan siswa menentukan panjang sisi persegi yang belum diketahui dengan tepat, intrinsic certainty yang terlihat dari keyakinan siswa terhadap kebenaran informasi yang diperolehnya, dan perseverance yang terlihat saat siswa mempertahankan informasi yang diperolehnya. Siswa tidak langsung memahami soal saat pertama kali membacanya yang berarti bahwa siswa tidak menunjukkan adanya karakteristik direct self-evidence. Argumen siswa yang menyatakan bahwa informasi yang diperolehnya masih belum cukup untuk menjawab soal menunjukkan bahwa subjek tidak memaksakan kebenaran informasi yang diperolehnya, ini berarti siswa tidak memperlihatkan karakteristik coerciveness. Siswa tidak merepresentasikan informasi yang ditemukannya pada lembar jawaban sehingga siswa tidak menunjukkan karakteristik globality.

Dalam tahap membuat rencana, siswa dengan kemampuan matematika sedang menggunakan intuisi anticipatory dengan karakteristik ide global, hasil ini sesuai dengan penelitian dari Nazariah dkk (2017). Siswa menemukan ide pemecahan masalah itu melalui informasi yang didapatkannya dari soal tanpa bantuan informasi lain dari luar. Siswa menggunakan rumus luas segitiga dan jajargenjang untuk menentukan luas yang diarsir, adapun ukuran alas dan tinggi yang digunakan siswa untuk menentukan luas yang diarsir didapatkan berdasarkan perkiraan ukuran pada gambar yang tertera pada soal. Hal ini secara tidak langsung menunjukkan bahwa siswa menyimpulkan ide penyelesaian secara umum setelah melihat bentuk daerah yang diarsir. Siswa juga menyatakan bahwa ide yang dia temukan itu sudah pasti benar.

Dalam tahap melaksanakan rencana, siswa dengan kemampuan matematika sedang tidak menggunakan intuisi, hasil ini sesuai dengan penelitian oleh Murdika (2013). Siswa melaksanakan ide awal yang sudah direncanakan tanpa ada penambahan atau pengurangan ide. Walaupun siswa menyatakan adanya kendala tetapi kendala itu hanya berupa kesulitan dalam menentukan rencana awal yang akan digunakan dan tidak menyebabkan perubahan terhadap rencana yang telah ditentukan, sehingga siswa tidak menggunakan intuisi dan hanya menggunakan operasi aljabar.

Dalam tahap memeriksa kembali, siswa dengan kemampuan matematika sedang tidak menggunakan intuisi. Setelah siswa menemukan hasil akhir, yang dilakukan selanjutnya adalah memeriksa kembali.
Cara yang dilakukan yaitu mengulang perhitungan yang telah dilakukan dan memeriksa apabila ada kesalahan dalam penulisan. Kegiatan itu digunakan sebagai dasar dalam menentukan penyelesaian masalah.

3. Karakteristik intuisi siswa yang memiliki kemampuan matematika rendah dalam memecahkan masalah matematika

Dalam tahap memahami masalah, siswa berkemampuan matematika rendah menggunakan intuisi affirmatory, hasil ini sesuai dengan penelitian dari Nazariah dkk (2017). Adapun karakteristik yang terlihat pada siswa adalah perseverance yang terlihat saat siswa mempertahankan informasi yang diperolehnya, dan coerciveness yang terlihat saat siswa memaksakan kebenaran informasi yang diperolehnya. Siswa tidak langsung memahami soal saat pertama kali membacanya yang berarti bahwa siswa tidak menunjukkan adanya karakteristik direct selfevidence. Siswa tidak dapat menentukan dengan tepat panjang sisi persegi yang lain menggunakan informasi yang sudah ada, ini menunjukkan bahwa siswa tidak menunjukkan karakteristik extrapolativeness. Siswa sendiri tidak merasa yakin apakah informasi yang diperolehnya benar atau tidak, ini berarti siswa tidak menunjukkan indikator intrinsic certainty. Siswa tidak merepresentasikan informasi yang ditemukannya pada lembar jawaban sehingga siswa tidak menunjukkan karakteristik globality.

Dalam tahap membuat rencana, siswa dengan kemampuan matematika rendah menggunakan intuisi anticipatory dengan karakteristik ide global, hasil ini sesuai dengan penelitian oleh Murdika (2013). Siswa menemukan ide pemecahan masalah itu melalui informasi yang didapatkan dari soal tanpa bantuan informasi lain dari luar. Siswa menggunakan rumus $\frac{1}{2}$ $\times$ alas $\times$ tinggi untuk menentukan luas yang diarsir, adapun ukuran alas dan tinggi yang digunakan siswa untuk menentukan luas daerah yang diarsir didapatkan dengan memperkirakan berdasarkan informasi yang ditemukan oleh subjek. Hal ini secara tidak langsung menunjukkan bahwa siswa menyimpulkan ide penyelesaian secara umum berdasarkan informasi yang dimilikinya.

Dalam tahap melaksanakan siswa dengan kemampuan matematika rendah tidak menggunakan intuisi. Siswa melaksanakan ide awal yang sudah direncanakan tanpa ada penambahan atau pengurangan ide. Walaupun siswa menyatakan adanya kendala tetapi kendala itu hanya berupa kesalahan penulisan dan tidak menyebabkan perubahan terhadap rencana 
yang telah ditentukan, sehingga siswa tidak menggunakan intuisi dan hanya menggunakan operasi aljabar.

Dalam tahap memeriksa kembali, siswa dengan kemampuan matematika rendah tidak menggunakan intuisi. Setelah siswa menemukan hasil akhir, yang dilakukan selanjutnya adalah memeriksa kembali. Cara yang dilakukan yaitu mengulang perhitungan yang telah dilakukan dan memeriksa apabila ada kesalahan dalam penulisan. Kegiatan itu digunakan sebagai dasar dalam menentukan penyelesaian masalah.

Tabel 2. Hasil Penelitian

\begin{tabular}{|c|c|c|c|c|}
\hline \multirow{2}{*}{$\begin{array}{c}\text { Sis } \\
\text { wa }\end{array}$} & \multicolumn{4}{|c|}{ Intuisi pada tahapan pemecahan masalah } \\
\cline { 2 - 5 } & $\begin{array}{c}\text { memahami } \\
\text { masalah }\end{array}$ & $\begin{array}{c}\text { membuat } \\
\text { rencana }\end{array}$ & $\begin{array}{c}\text { melaksa } \\
\text { nakan } \\
\text { rencana }\end{array}$ & $\begin{array}{c}\text { memeri } \\
\text { ksa } \\
\text { kembali }\end{array}$ \\
\hline $\begin{array}{c}\text { ting } \\
\text { gi }\end{array}$ & Affirmatory & Anticipato & Tanpa & Tanpa \\
sed & Affirmatory & Anticipato & Tanpa & Tntuisi \\
ang & & ry & Intuisi & Intuisi \\
\hline ren & Affirmatory & Anticipato & Tanpa & Tanpa \\
dah & & ry & Intuisi & Intuisi \\
\hline
\end{tabular}

\section{PENUTUP}

\section{Kesimpulan}

Berdasarkan hasil penelitian dan pembahasan, dapat ditarik kesimpulan sebagai berikut:

1. Karakteristik intuisi siswa SMP yang memiliki kemampuan matematika tinggi dalam memecahkan masalah matematika

Saat memahami masalah, siswa dengan kemampuan matematika tinggi menggunakan intuisi affirmatory dengan karakteristik extrapolativeness, intrinsic certainty, dan perseverance. Saat membuat rencana, siswa menggunakan intuisi anticipatory dengan karakteristik ide global. Saat melaksanakan rencana, siswa tidak menggunakan intuisi dan hanya melanjutkan rencananya. Saat memeriksa kembali, siswa tidak menggunakan intuisi dan hanya mengulang langkah perhitungan yang telah dilakukannya.

2. Karakteristik intuisi siswa SMP yang memiliki kemampuan matematika sedang dalam memecahkan masalah matematika

Saat memahami masalah, siswa dengan kemampuan matematika sedang menggunakan intuisi affirmatory dengan karakteristik extrapolativeness, intrinsic certainty, dan perseverance. Saat membuat rencana, siswa menggunakan intuisi anticipatory dengan karakteristik ide global. Saat melaksanakan rencana, siswa tidak menggunakan intuisi dan hanya melanjutkan rencananya. Saat memeriksa kembali, siswa tidak menggunakan intuisi dan hanya mengulang kembali langkah perhitungan yang telah dilakukannya.

3. Karakteristik intuisi siswa SMP yang memiliki kemampuan matematika rendah dalam memecahkan masalah matematika

Saat memahami masalah, siswa dengan kemampuan matematika rendah menggunakan intuisi affirmatory dengan karakteristik perseverance, dan coerciveness. Saat membuat rencana, siswa menggunakan intuisi anticipatory dengan karakteristik ide global. Saat melaksanakan rencana, siswa tidak menggunakan intuisi dan hanya melanjutkan rencananya. Saat memeriksa kembali, siswa tidak menggunakan intuisi dan hanya mengulang kembali langkah perhitungan yang telah dilakukannya.

Saran

Berdasarkan hasil penelitian, peneliti mengemukanan beberapa saran sebagai berikut.

1. Masalah pada penelitian ini hanya dibatasi pada materi segiempat. Maka dari itu, bagi peneliti selanjutnya dapat mengembangkan tes pemecahan masalah dengan menggunakan materi lain.

2. Teori intuisi yang dikaji pada penelitian ini hanya dibatasi pada teori intuisi Fischbein. Maka dari itu, peneliti selanjutnya disarankan untuk mengembangkan penelitian menggunakan kajian teori intuisi yang dikembangkan oleh ilmuan lain.

3. Disarankan bagi peneliti selanjutnya untuk mengambil lebih dari satu subjek pada setiap kategori kemampuan matematika. Dengan cara itu diharapkan peneliti selanjutnya akan mendapatkan data intuisi siswa yang lebih beragam.

\section{DAFTAR PUSTAKA}

Dahlan, J.A. 2011. Analisis Kurikulum Matematika. Jakarta: Universitas Terbuka.

Fischbein, Efraem. 1987. Intuition in Science and Mathematics. Israel: school of educaton tel aviv university.

Fischbein. 2002. Intuition in Science and Mathematics: An Educational Approach. Dordrecht: Kluwer Academic Publishers.

Hudojo, Herman. 2005. Pengembangan Kurikulum dan Pembelajaran Matematika. Malang: UM PRESS.

Minggi, Ilham. 2010. Profil Intuisi Mahasiswa Dalam Memahami Konsep Limit Fungsi Berdasarkan Perbedaan Gender. Disertasi tidak diterbitkan. Surabaya: Pascasarjana UNESA Surabaya.

Murdika dan Budiarto, Mega Teguh. 2013. "Profil Intuisi Siswa SMP Dalam Memecahkan Masalah Geometri Ditinjau Dari Kemampuan Matematika 
Siswa". Jurnal Pendidikan Matematika. Volume 01 nomer 01: hal. 2 .

Nazariah, dkk. 2017. "Intuisi Siswa SMK dalam Memecahkan Masalah Matematika Ditinjau dari Kemampuan Matematika dan Perbedaan Gender". Jurnal Dikdaktik Matematika. Volume 04, no. 01.

Polya, G. 2004. How to Solve It. New Jersey: Princeton Science Library.

Rahmadani, A.Y. 2012. Profil Pemecahan Masalah Geometri Siswa ditinjau dari Gaya Kognitif Impulsif-Reflektif. Tesis tidak diterbitkan. Surabaya: Pasca Sarjana UNESA.

Sabandar, J. dan Hasanah, A. 2010. "Mengembangkan Kemampuan Berpikir Kreatif Siswa Sekolah Menengah Atas (SMA) melalui Pembelajaran Kontekstual yang Menekankan pada Intuisi
Matematis". Prosiding Seminar Nasional Matematika Universitas Negeri Yogyakarta.

Sukmawati, Dinah Dessy. 2015. Proses Berpikir Kreatif Siswa SMP dalam Menyelesaikan Masalah Matematika Open-ended ditinjau dari Kemampuan Matematika. Skripsi tidak diterbitkan. Surabaya: Universitas Negeri Surabaya.

Usodo, Budi. 2011. Karakteristik Inuisi Siswa SMA dalam Memecahkan Masalah Matematika Ditinjau dari Kemampuan Matematika dan Perbedaan Gender. Disertasi tidak diterbitkan. Surabaya: Pascasarjana UNESA Surabaya.

Usodo, Budi. 2012. "Karakteristik Inuisi Siswa SMA dalam Memecahkan Masalah Matematika Ditinjau dari Kemampuan Matematika dan Perbedaan Gender". AKSIOMA. Volume 01 nomor 01. 